\section{ROYAL SOCIETY ELECTIONS}

THE Council of the Royal Society is submitting the following for election on March 21 as fellows of the Society:

Dr. Agnes ARBer, of Cambridge, distinguished for her outstanding contributions to the elucidation of the morphology of flowering plants, especially the monocotyledons.

Prof Wilson BaKer, professor of organic chemistry, University of Bristol, distinguished particularly for structural work relating to the natura] colouring matters, and for important contributions to the theory of chelate compounds in the aromatic series.

G. L. BRown, medical member of the staff of the Medical Research Council, distinguished for his investigations in the chemical transmission of nerve impulses through sympathetic ganglia, and from nerve to skeletal muscle.

Prof. G. R. CAmeron, professor of pathology, University College Hospital, London, who has made distinguished contributions to our knowledge of changes produced in the liver and other organs by operative procedures and by toxic chemicals.

Dr. F. Drckens, director of research of the North of England Branch of the British Empire Cancer Campaign, distinguished for ingenious improvements in manometric methods, and for investigations of the metabolism of animal tissues, especially in relation to tumours.

Dr. H. J. Emeleus, reader in inorganic chemistry, University of Cambridge, distinguished for his researches in modern inorganic chemistry, in particular the compounds of silicon and of fluorine.

Sir Frank ENGledow, professor of agriculture, University of Cambridge, and director of the Imperial Bureau of Genetics, distinguished for his great assistance in maintaining and raising the standard of scientific development in agriculture both at home and in the Colonies.

DR. E. B. Ford, reader in genetics, University demonstrator in the Department of Zoology and Comparative Anatomy, Oxford, distinguished for his experimental researches in genetics and the elucidation of ecological and evolutionary situations.

Dr. R. A. Frazer, of the National Physical Laboratory, distinguished for his work on aeronautics, particularly on problems of flutter, combining mathematical work with great experimental skill and ingenuity.

C. D. GiBB, director-general of armoured fighting vehicles, chief engineer and joint managing director of Messrs. C. A. Parsons and Co., Ltd., distinguished for original research and design and for introduction of new methods of manufacture in connexion with steam turbines; also for work of great national importance on various types of armament in the War.

Dr. E. A. GugGenherm, lecturer in chemical thermodynamics, Imperial College of Science and Technology, London, distinguished for his authoritative contributions to thermodynamics and statistical mechanics.

R. Hrwr, member of staff of the Agricultural Research Council (Cambridge), distinguished for his researches in hæmoglobin and tetrapyrrolic compounds, and upon the photochemical production of oxygen by isolated chloroplasts ; the latter has opened up a new biochemical approach.

Dr. Ernest Marsden, distinguished for his earlier work on radiozctivity, including the scattering of $\alpha$-particles by the nucleus, and later as director of scientific developments in New Zealand, where he has been largely responsible for the direction of the Dominion's scientific work in both peace and war.

DR. W. G. PENNEY, assistant professor of mathematics, Imperial College of Science and Technology, London, distinguished for his theoretical investiga. tions on molecular structure and related subjects; during the War he has made valuable contributions to the understanding of explosion waves.

Prof. J. T. RANDALL, professor of physies, University of St. Andrews, distinguished both for his researches on the luminescence of solids and liquids and for his outstanding contributions to the generation of high-frequency radio waves.

DR. R. O. REDman, chief assistant at the Radcliffe Observatory, Pretoria, distinguished for his many contributions to observational astronomy and astrophysics.

Prof. A. R. Richardson, of Cape Town, formerly professor of mathematics at University College, Swansea, distinguished for his researches in algebra, including non-associative algebras, generalized determinants and group characters.

Prof. L. Rosenhead, professor of applied mathematics, University of Liverpool, distinguished for his researches in hydrodynamics and aerodynamics, which have contributed to the fuller understanding of vortex motion; during the War he led a team of mathematicians working on rocket projectiles.

Brigadier J. A. Sinton, V.C., consultant malariologist to the War Office; as director of the Malaria Survey of India during nine years, he contributed greatly to the knowledge of all aspects of malaria.

Dr. H. H. Storey, of Nairobi, plant pathologist, one of the foremost workers on virus diseases of plants, who has made noteworthy investigations on the role of insect-vectors in the transmission of such diseases.

DR. H. W. THомpson, University demonstrator in chemistry, Oxford, distinguished for his researches on the application of spectroscopic methods to chemical problems, in particular the development of infra-red technique.

J. W. Trevan, director of the Welleome Physiological Laboratories, distinguished for numerous researches in pharmacology, and especially for his contributions to methods of biological assay and to the 'error of determination of toxicity'.

Prof. L. R. WAGER, professor of geology, University of Durham, distinguished for his contributions to petrology, particularly for his work in East Greenland, in Ireland and in the Himalayas.

DR. F. M. R. WALSHE, physician to the National Hospital, Queen Square, London, editor of Brain, distinguished for his physiological studies on the human nervous system by clinical investigations.

Prof. C. M. Yonge, regius professor of zoology, University of Glasgow, distinguished as an invertebrate zoologist, more particularly in the field of the Mollusca; as leader of the Great Barrier Reef Expedition, he was responsible for the organisation of the work and for his own studies on corals. 